\title{
PCR diagnosis and in vitro sanitation of the papaya MSXJ hybrid with ringspot virus disease
}

\author{
Mariel González-Lázaro', Francisco Hernández-Rosas², Fernando Carlos Gómez-Merino², \\ Miriam Cristina Pastelín-Solanoํㅜ, Javier Emanuel Bulbarela-Marini' ${ }^{1}$, Luis Alberto Solano-Rodríguez ${ }^{3}$, \\ and Odón Castañeda Castro ${ }^{*}$
}

'Universidad Veracruzana, Facultad de Ciencias Químicas, Prolongación de Oriente 6•\# 1009, Colonia Rafael Alvarado, CP 94340 Orizaba, Veracruz, México. .Corresponding author (odcastaneda@uv.mx).

${ }^{2}$ Colegio de Postgraduados, km 348 Carretera Federal Córdoba-Veracruz, Congregación Manuel León, Municipio de Amatlán de los Reyes, CP 94953 Veracruz, México.

${ }^{3}$ Laboratorio de Biotecnología Agrícola CIVAGRO (Centro de Investigación y Validación Agropecuaria S.C.), Avenida Eugenio Garza Sada 1, CP 94500 Córdoba, Veracruz, México.

Received: 28 November 2018; Accepted: 22 March 2019; doi:10.4067/S0718-58392019000300376

\begin{abstract}
Papaya (Carica papaya L.) is a tropical fruit with a high nutritional value. Current problems affecting its cultivation are the limited number of exploited varieties and its susceptibility to pests and diseases. The papaya MSXJ hybrid is resistant to pests and diseases, and its organoleptic characteristics are prominent compared with most papaya genotypes on the market. Samples of Papaya ringspot virus (PRSV) disease were evaluated by in vitro culture of the apical meristems and thermotherapy. Sanitation of apical meristems was accomplished by regenerating them with or without light and thermotherapy was performed at 40 and $45^{\circ} \mathrm{C}$ for 4 and $7 \mathrm{~h}$, respectively. Both situations were observed for $45 \mathrm{~d}$ to evaluate survival, regeneration, and sanitation by reverse transcription polymerase chain reaction (RT-PCR). In vitro culture of the meristems in total darkness obtained the highest survival rate (87\%) and regeneration (22\%) compared with the treatments under photoperiod $(21 \%$ and $18 \%$, respectively). Under both study conditions, sanitation in PRSV was $100 \%$ of the meristems. Plants subjected to thermotherapy showed a higher survival rate $(99.92 \%)$ at $40{ }^{\circ} \mathrm{C}$ for $4 \mathrm{~h}$ and sanitation of $80.2 \%$.
\end{abstract}

Key words: Apical meristems, Carica papaya, Papaya ringspot virus (PRSV), RT-PCR, thermotherapy.

\section{INTRODUCTION}

Papaya (Carica papaya L.) is a fruit with high economic and nutritional importance for Mexico; the State of Veracruz has the largest arable area despite numerous phytosanitary problems (Megchún-García et al., 2017). Papaya ringspot virus (PRSV) is a viral disease transmitted by aphids; it affects production and productivity in all regions of the world because plants of all ages are vulnerable to this disease and generally present symptoms after 3 or 4 wk of infection (Kumar et al., 2010). There are methods to control PRSV such as quarantine, geographic dispersion, elimination of undesirable plants, meshing, cross protection, and genetic modification of the host plant (Chalak et al., 2017). The MSXJ hybrid can tolerate temperatures over $35^{\circ} \mathrm{C}$ during the flowering stage and produce fruits with desirable market characteristics, that is, on average, $1.5 \mathrm{~kg}$ firm pulp with red coloration and low rates of carpelloid fruits and fruit abortion (Mirafuentes and Santamaría-Basulto, 2014). However, the development of a technological package that allows planting and commercial production of papaya is urgently needed given the severity of the problem (Valderrama et al., 2015). The methods to detect and identify viruses are critical for disease management and these should be the most convenient, effective, specific, and rapid (González-Garza, 2017). Reverse transcription polymerase chain reaction (RT-PCR) amplifies millions of times 
a specific sequence of cDNA obtained from RNA (Tamay et al., 2013). Some biotechnological techniques, such as the in vitro culture of apical meristems and apex thermotherapy, are used to eliminate viruses in many crops (Dugassa and Feyissa, 2011). The first technique is based on the non-uniform distribution of microorganisms (viruses, bacteria, and mycoplasmas) toward the stem apex (Solís et al., 2011). The second consists of the thermal treatment of plant parts in temperature/time regimes that kill the pathogen and are only slightly harmful to the host (Grondeau et al., 1994). There are currently no reports on the use of thermotherapy to repair PRSV-infested papaya plants. The objective of this study was to evaluate sanitation by in vitro culture of apical meristems using thermotherapy in PRSV positive papaya MSXJ hybrid plants and RT-PCR.

\section{MATERIALS AND METHODS}

\section{Plant material and molecular diagnosis}

Hermaphrodite plants of 8-mo-old papaya MSXJ hybrid in the production stage were diagnosed for Papaya ringspot virus (PRSV) by the reverse transcription polymerase chain reaction (RT-PCR) technique. Total RNA was extracted following the TRIsure protocol (Bioline, London, UK); TRIsure, chloroform, and isopropyl alcohol were added, washed with ethanol, and dissolved in water treated with diethyl pyrocarbonate.

The retrotranscription and polymerase chain reaction were performed according to the methodology described by Tuo et al. (2014). The RNA was incubated in a thermal cycler (Apollo ATC 201, Nyx Technik, San Diego, California, USA); an extension was made, a reaction mixture was prepared to construct the complementary chain consisting of M-MLV (5X) buffer (Bioline, London, UK), dNTP (Bioline), RNAsin (Promega, Madison, Wisconsin, USA), M-MLV (Bioline), first PRSV-613R (CGAATGTCATCCAAAGACTGATGATAAAC), and Milli-Q water, which was incubated for 2 min in a thermal cycler.

The cDNA was amplified by PCR with 5X PCR buffer (Bioline), $\mathrm{MgCl}_{2}(25 \mathrm{mM})$, dNTP, Primers PRSV-613F (TTGTGTACGACTTCTCACCGAA) and PRSV-613R (CGAATGTCATCCAAAGACTGATGATAAAC), Go-Taq DNA Polymerase (Bioline) enzyme, and Milli-Q grade water with initial denaturation and second stage alignment, elongation, and extension of a $613 \mathrm{bp}$ long fragment (Tuo et al., 2014).

Electrophoresis was performed on $2 \%$ agarose gels with ethidium bromide and TAE $1 \mathrm{x}$ buffer. The gel was loaded with $10 \mu \mathrm{L}$ of each of the samples with a PRSV positive control, a 100 bp ladder molecular weight marker (Axygen Scientific, Fisher Scientific, Madrid, Spain) was run in a power source (PowerPacTM Basic, BioRad, Hercules, California, USA), and bands were visualized in a DNA Light UV transilluminator (Labnet International, Edison, New Jersey, USA).

\section{Establishment of aseptic culture and propagation of plants with PRSV}

Establishment of the aseptic culture was done with 3 to $5 \mathrm{~cm}$ apices planted in $100 \mathrm{~mL}$ capacity culture tubes containing 15 $\mathrm{mL}$ MS culture medium supplemented with $150 \mathrm{mg} \mathrm{L}^{-1}$ citric acid, $50 \mathrm{mg} \mathrm{L}^{-1}$ ascorbic acid, $10 \mathrm{mg} \mathrm{L}^{-1}$ adenine, $2.219 \mu \mathrm{M}$ benzylaminopurine, $2.854 \mu \mathrm{M}$ indoleacetic acid, $30 \mathrm{~g} \mathrm{~L}^{-1}$ sucrose, and $2.3 \mathrm{~g} \mathrm{~L}^{-1}$ phytagel as a gelling agent; culture tubes were sterilized in an autoclave (LAC5060s; Daihan LabTech, Namyangju, South Korea) at $120^{\circ} \mathrm{C}$ for $20 \mathrm{~min}$. After 40 $\mathrm{d}$, the micropropagation of established and PRSV positive plants was performed in an MS culture medium supplemented with $100 \mathrm{mg} \mathrm{L}^{-1}$ ascorbic acid, $0.2887 \mu \mathrm{M}$ gibberellic acid $\left(\mathrm{GA}_{3}\right), 0.2685 \mu \mathrm{M}$ naphthalene acetic acid (NAA), $2.219 \mu \mathrm{M}$ benzylaminopurine (BAP), $30 \mathrm{~g} \mathrm{~L}^{-1}$ sucrose, and $2.3 \mathrm{~g} \mathrm{~L}^{-1}$ phytagel in $200 \mathrm{~mL}$ capacity bottles containing $30 \mathrm{~mL}$ culture medium; subcultures were performed every $30 \mathrm{~d}$ using the same methodology.

\section{Sanitation by in vitro culture of meristems and thermotherapy}

The in vitro culture of apical meristems was carried out following the protocol established by Solís et al. (2011) using a stereoscope microscope; the $0.3 \mathrm{~mm}$ apical meristems were extracted and cultivated in MS medium supplemented with $0.4439 \mu \mathrm{M}$ BAP, $0.5708 \mu \mathrm{M}$ indole acetic acid (IAA), $30 \mathrm{~g} \mathrm{~L}^{-1}$ sucrose, and $2.3 \mathrm{~g} \mathrm{~L}^{-1}$ phytagel. The meristem culture remained under a $16: 8 \mathrm{~h}$ light dark photoperiod and etiolation, both at $24 \pm 1{ }^{\circ} \mathrm{C}$ room temperature. Thermotherapy of MSXJ hybrid PRSV positive vitroplants was performed according to the method described by Torres et al. (2013) in which $1 \mathrm{~cm}$ long apices were used: these were deposited in $200 \mu \mathrm{L}$ capacity microcentrifuge tubes that contained $100 \mu \mathrm{L}$ liquid culture medium using the formulation proposed by Solís et al. (2011). Temperature was intended to be uniform 
and tubes were incubated in a thermal cycler (Axygen MaxyGen II, Corning Inc., Tewksbury, Massachusetts, USA) at 40 and $45{ }^{\circ} \mathrm{C}$ for 7 and $4 \mathrm{~h}$, respectively. Apices were subsequently cultivated in the semi-solid culture medium in the composition described above and for $16: 8 \mathrm{~h}$ light dark photoperiod regeneration at $24 \pm 1{ }^{\circ} \mathrm{C}$.

\section{Experimental conditions and experimental design}

The study had a completely randomized design and the experimental variables were a) meristem culture, photoperiod, and etiolation tested for $40 \mathrm{~d}$ and b) thermotherapy. In the second treatment, two temperature gradients $\left(40\right.$ and $\left.45^{\circ} \mathrm{C}\right)$ and times ( 4 and $7 \mathrm{~h}$ ) were established, and treatments were randomly established with a binomial response variable. Five replicates were used for both variables in each treatment; each replicate consisted of nine established meristems for apical meristem culture, while three apices were used for thermotherapy.

\section{Statistical analyses of data}

Our data were statistically analyzed using the GLIMMIX procedure (PROC GLIMMIX) binomial in the SAS statistical version 9.4 software (SAS Institute, Cary, North Carolina, USA) with a comparison of means by Fisher's LSD test with a 0.05 level of significance.

\section{RESULTS}

\section{Molecular diagnosis by RT-PCR in MSXJ hybrid plants}

Tissue staining confirming the presence of PRSV (613 bp) (Tuo et al., 2014) in seven of the eight examined samples (lanes $1,2,3,4,6,7$, and 8 ) can be seen in tissue from the in vivo culture of the MSXJ hybrid stock plants. This showed $87.5 \%$ incidence of PRSV in plants of this hybrid established in the field (Figure 1).

\section{In vitro culture of meristems}

As for survival of meristems grown in vitro, there was a significant difference between the culture conditions in which tissues kept without exposure to light for the 45 -d evaluation had better results (87\%) compared with $21 \%$ of meristems exposed to the photoperiod for the same time period (Figure 2).

Figure 1. Agarose gel electrophoresis $2 \%$ with DNA reverse transcription polymerase chain reaction (RT-PCR) of papaya MSXJ hybrid collected in the field. Lane c-: Negative control (healthy plant), Lane M: Molecular weight marker 1 kb, Lane 5: absence of band (negative for Papaya ringspot virus [PRSV]) and lanes 1, 2, 3, 4, 6, 7, and 8 coloration in bands (positive for PRSV).

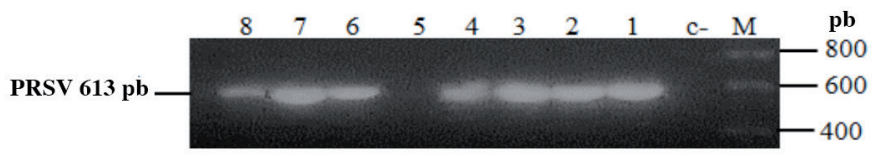

Figure 2. Survival of the apical meristems of the papaya MSXJ hybrid cultivated in vitro under etiolation and photoperiod conditions.

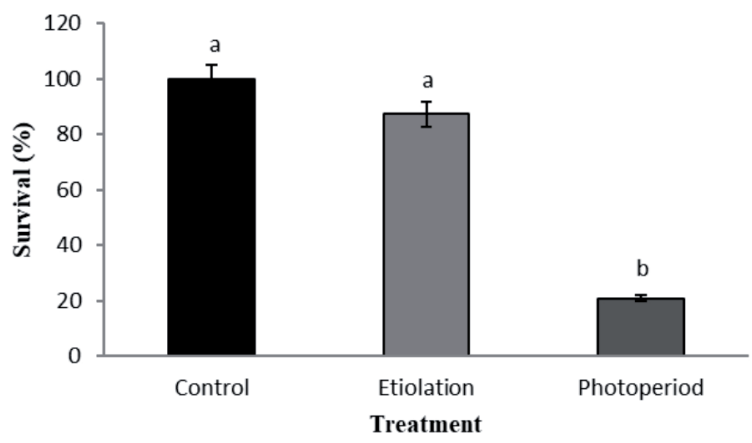

Error bars indicate the standard error. Different letters indicate significant differences $(\mathrm{p} \leq 0.05)$. 
Regeneration and differentiation of surviving apical meristems, plants kept in total darkness for $45 \mathrm{~d}$ resulted in a value of $22 \%$ compared with $18 \%$ for vitroplants established under photoperiod conditions. However, these results did not represent a significant difference between both treatments (Figure 3).

Plants from the meristem culture showed regeneration and differentiation characteristics such as the increase of plant mass in the tissues as well as the appearance of leaves and shoots. The 100\% effectiveness for PRSV elimination was demonstrated by the culture of apical meristems developed under both etiolation and photoperiod. Results for sanitation by meristem culture were checked by RT-PCR (Figure 4).

\section{Thermotherapy}

Results for apex survival under the combined temperature and time treatments in the thermotherapy are shown in Figure 5.

As for the survival of healthy plants, combining the heat treatment $\left(40\right.$ and $\left.45^{\circ} \mathrm{C}\right)$ for 4 or $7 \mathrm{~h}$ determined that the highest survival rate occurred at $40{ }^{\circ} \mathrm{C}$ for $4 \mathrm{~h}$ with $99.92 \%$ success. Despite not finding a significant difference with the $45{ }^{\circ} \mathrm{C}$ for $4 \mathrm{~h}$ combination (53.24\%), it was visually different. Similarly, it was observed at $40{ }^{\circ} \mathrm{C}$ for $7 \mathrm{~h}(26.48 \%)$ and with the treatments using the highest temperature and time values $(13.26 \%)$.

It can be seen that tissues in better conditions of survival and vigor were obtained by establishing them by the thermotherapy technique at $40^{\circ} \mathrm{C}$ for $4 \mathrm{~h}$; this temperature also proved to be the best in the combination with the maximum number of hours $(7 \mathrm{~h})$ for in vitro plants. Conversely, the environment at $45^{\circ} \mathrm{C}$ was less favorable for vitroplants of this hybrid; despite finding some survivors at $4 \mathrm{~h}$ of exposure, these percentages were reduced for $7 \mathrm{~h}$ of exposure.

Figure 3. Regeneration of apical meristems of the papaya MSXJ hybrid grown in vitro under etiolation and photoperiod conditions. The control is the papaya MSXJ hybrid, positive for Papaya ringspot virus (PRSV) without treatment.

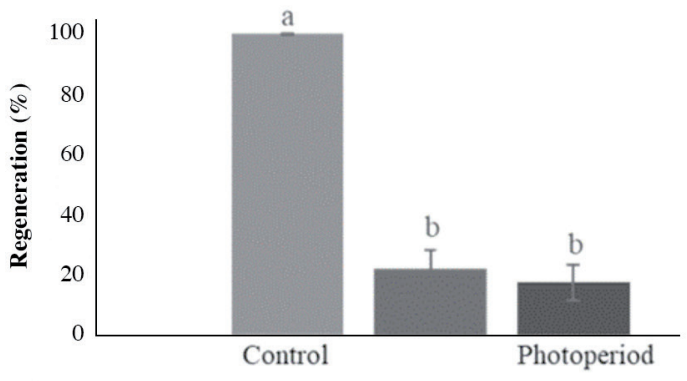

Error bars indicate the mean of the standard error (LSD Test). Different letters indicate significant differences $(\mathrm{p} \leq 0.05)$.

Figure 4. Electrophoresis of the meristem culture: Samples with the plant controls with Papaya ringspot virus (PRSV) inoculum without treatments (a and b); samples of meristems under photoperiod (c); samples of the meristems under etiolation analyzed by reverse transcription polymerase chain reaction (RT-PCR) (d). Lane C+: Sample as a positive plant control for PRSV. Lane C-: Healthy plant sample as negative control. Lane MM: HyperLadder molecular weight marker 1 kb (Axygen).

a)

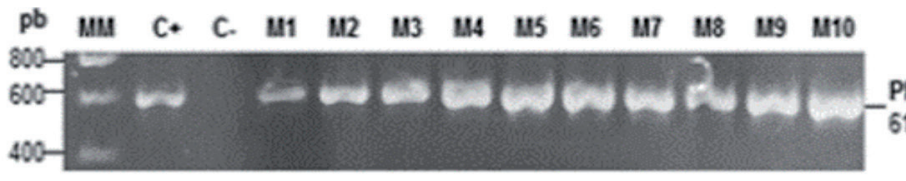

b)

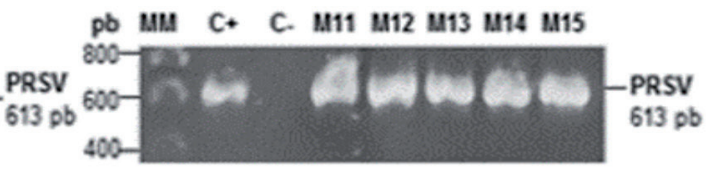

c)

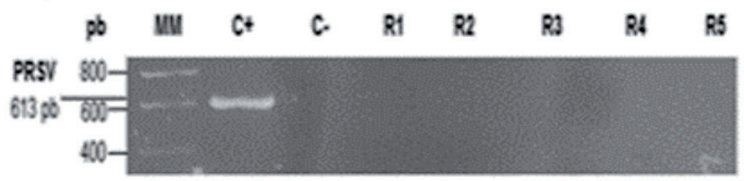

d)

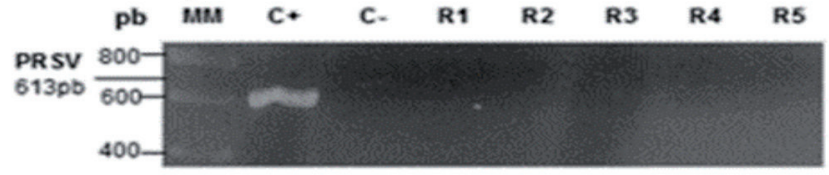


Figure 5. Influence of temperature and time on the survival of positive Papaya ringspot virus (PRSV) plants of the papaya MSXJ hybrid. The control is the papaya MSXJ hybrid, positive for PRSV without treatment.

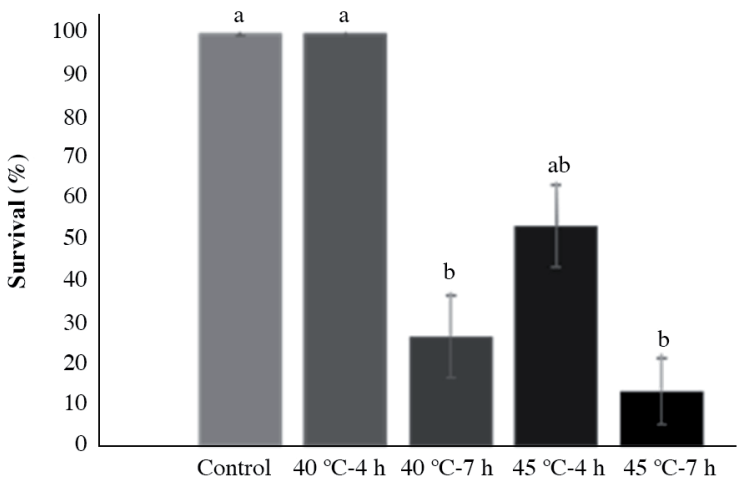

Error bars indicate the mean of the standard error (LSD Test). Different letters indicate significant differences $(\mathrm{p} \leq 0.05)$.

Figure 6 shows the response of the time and temperature combination of in vitro thermotherapy for the sanitation of PRSV positive plants.

Regarding the best combination to achieve PRSV inactivation in plants exposed to the thermotherapy technique, it was determined that the best interaction between temperature and time factors was $40{ }^{\circ} \mathrm{C}$ for $4 \mathrm{~h}$ with $80.2 \%$ success. The treatment with the second best results $(46.7 \%)$ was tissue exposure at $45^{\circ} \mathrm{C}$ for the same time period $(4 \mathrm{~h})$.

The effectiveness of the aforementioned treatments was checked by the RT-PCR technique and could be visualized with $2 \%$ agarose gels; these images are presented in Figure 7.

\section{DISCUSSION}

\section{Molecular diagnosis by RT-PCR in MSXJ hybrid plants}

Our results were similar to those reported by Cabrera-Mederos et al. (2011) for 'Maradol' papaya plants established in the field that reached $93.40 \%$ without the use of anti-aphid mesh as a preventive measure. Although there was a reduction of the virus in $30 \%$ of the protected plantation, it showed that it is still only a temporary alternative to prevent the efficient dissemination of the disease by its vectors. In this way, and following the same line of study, Cabrera-Mederos et al. (2013) evaluated the performance of intercropped maize crops as natural barriers to reduce PRSV infections in the same variety of papaya, reducing it to $27 \%$. They also observed positive results in reducing the severity of this disease and attributed such effects to the cleaning of the stylet that the natural vectors of PRSV make in these plant barriers that help to

Figure 6. Influence of temperature and time on the survival of positive Papaya ringspot virus (PRSV) plants of the papaya MSXJ hybrid. Control is papaya MSXJ hybrid, positive for PRSV without treatment.

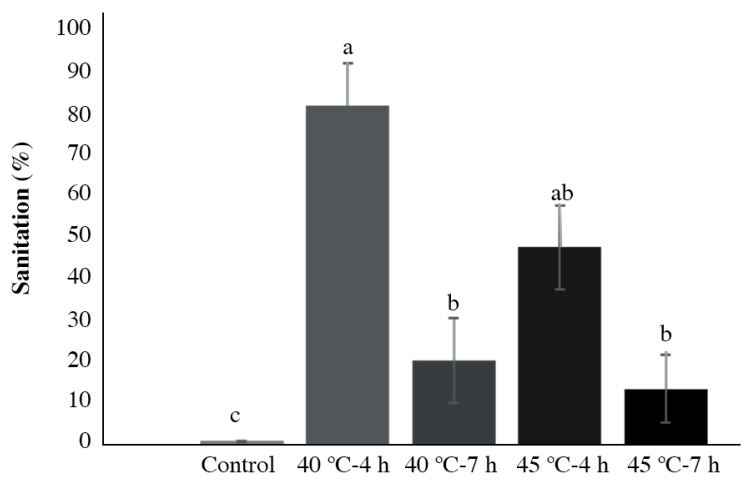

Error bars indicate the mean of the standard error (LSD Test). Different letters on the bars indicate significant differences $(\mathrm{p} \leq 0.05)$. 
Figure 7. Electrophoresis of thermotherapy plant survival analyzed by RT-PCR: Control, plants with Papaya ringspot virus (PRSV) without treatment (a and b); plants at $40^{\circ} \mathrm{C}$ for $4 \mathrm{~h}$ (c and d), plants at $40{ }^{\circ} \mathrm{C}$ for $7 \mathrm{~h}$ (e), plants at $45^{\circ} \mathrm{C}$ for 4 $\mathrm{h}(\mathrm{f})$, plants at $45^{\circ} \mathrm{C}$ for $7 \mathrm{~h}(\mathrm{~g})$. Lane c+: plant sample as a positive control for PRSV. Lane c-: plant sample as a negative control. Lane MM: HyperLadder molecular weight marker 1 kb (Axygen).

a)

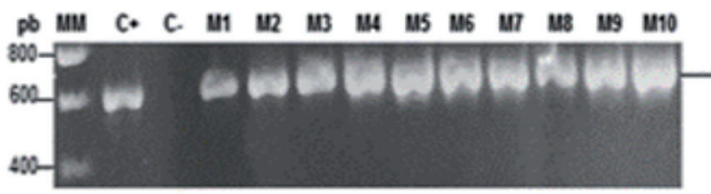

c)

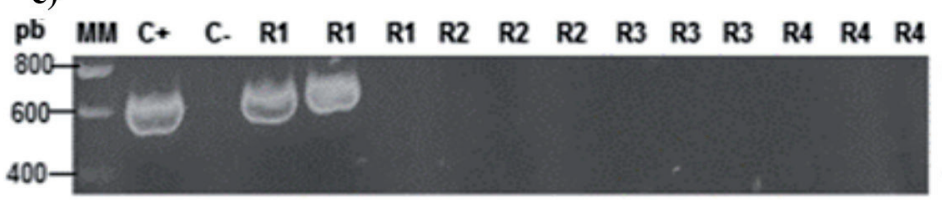

b)

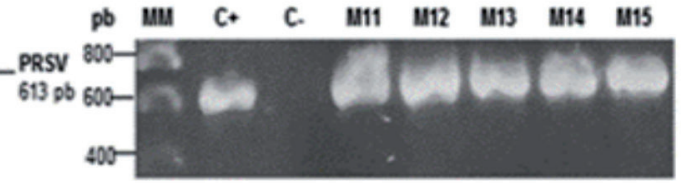

d)

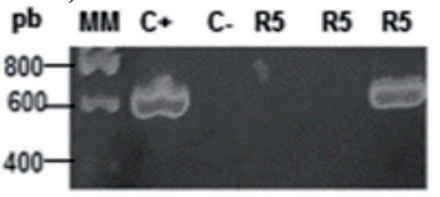

e)

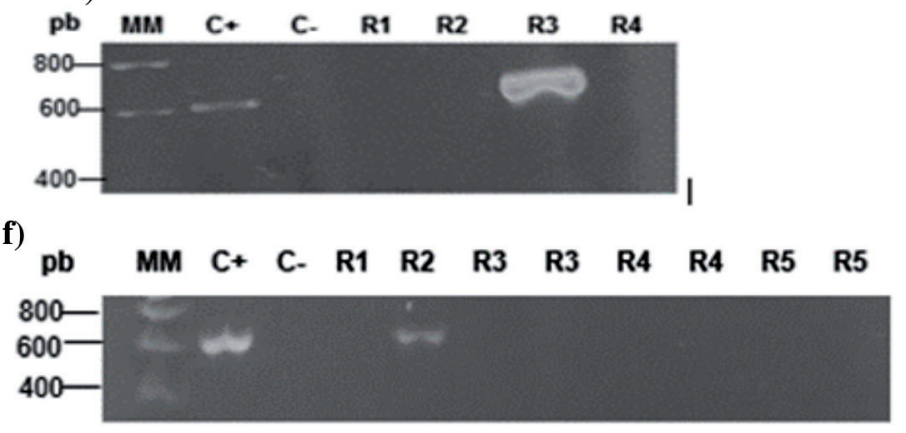

g)

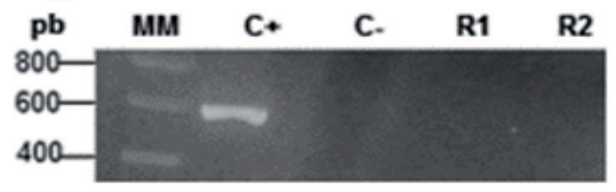

spread the disease because they are not hosts for this virus. It is important to emphasize the importance of a technological package comprised of early and accurate diagnoses, the use of varieties tolerant to this disease, and sanitation methods to eliminate viruses or at least reduce their titer to quantities that are not representative in order to provide healthy plants.

\section{In vitro culture of meristems}

The survival results of the explants grown in the dark achieved the highest number of live meristems, and these differ from those found by Solís et al. (2011), who obtained high percentages of surviving apical meristems without the etiolation variable during their growth. However, this study established the importance of exogenous stimulation by adding phytohormones, such as auxins, for the survival and development of meristematic tissues. This concurs with conclusions obtained by Vega-Celedón et al. (2016), who confirm the participation of these hormones in various plant functions such as apical dominance and survival and defense responses, as well as their intervention on phototropism. Thus, Maynard and Bassuk (1996) proved that the totally dark environment during the cultivation of Carpinus betulus L. apices, Fastigiata plants increased auxin concentration, resulting in a higher percentage of surviving apical tissues. Sánchez-Reyes et al. (2016) conclude that etiolation is correlated with an increase in auxins, favorably modifying their production, as well as the concentration of carbohydrates, which in addition to shoot proliferation also positively affects rooting. 
Results for the regeneration response under the treatments were similar to those indicated in the study by Solís et al. (2011) in which meristems of the regenerated papaya 'PTM-331' were obtained together with signs of differentiation without the use of etiolation as one of the growing conditions. These authors added IAA in the culture medium as a source of auxins and produced the regeneration process with conventional laboratory environment. However, the need for exogenous addition or stimulation for the endogenous production of these phytohormones in meristem culture is reaffirmed to achieve a higher success rate. Likewise, growth in the absence of light was used in a similar way in research by Rodrigues et al. (2017) in apices of Cattleya labiata. They explain the etiolation mechanism as a strategy by which plant tissues use their energy to elongate in search of light and also highlight the feasibility of using this treatment; among other positive effects, they observed the formation of more vigorous outbreaks that support the possibilities of higher new explant regeneration and formation rates.

The effectiveness of PRSV elimination was exhibited by the culture of apical meristems developed under both etiolation and photoperiod, whose guarantee for sanitation has been demonstrated in several commercially important crops. According to Cheong et al. (2012), the extraction of meristematic tissues smaller than $1 \mathrm{~mm}$ have a success rate from $61 \%$ to $92 \%$ in obtaining healthy sugarcane plants from mother plants contaminated with Sorghum mosaic virus (SrMV), Sugarcane yellow leaf virus (SCYLV), Sugarcane mosaic virus (SCMV), Fiji disease virus (FDV), and Sugarcane streak mosaic virus (SCSMV). Explant size is an important aspect to both regenerate the apical meristems and achieve sanitation. Bayoudh et al. (2017) found that the best tissue size to eradicate Feline calicivirus (FCV) and Fig mild mottle associated virus (FMMaV) (70\% to $90 \%$ success rates) in the Ficus carica L. species measured approximately $0.5 \mathrm{~mm}$; this agrees with research conducted in cassava in which Deepthi and Makeshkumar (2016) eliminated 100\% SCMV and Indian cassava mosaic virus (ICMV) when the 53 apical meristems were between 0.1 and $0.5 \mathrm{~mm}$, sizes very similar to those of the MSXJ hybrid $(0.3 \mathrm{~mm})$. In addition, studies conducted by Al-Taleb et al. (2011) and Hossain and Levy (2014) in potato showed the benefits of eliminating Potato virus Y (PVY) and Potato virus X (PVX) (75\% to 100\%), which are similar to PRSV because they are potyviruses and cause substantial economic losses in the crops they infect.

\section{Thermotherapy}

The effects of the best thermotherapy treatment combination concur with Dziedzic (2008) in plum experiments, the author concludes that the best temperatures were $38 / 36^{\circ} \mathrm{C}$ (day/night), and survival of plants subjected to thermotherapy methods is greater in those plants with lower applied temperatures for this procedure. However, sweet potato apices proposed for thermotherapy (Torres et al., 2013) showed a $100 \%$ survival rate at $40{ }^{\circ} \mathrm{C}$ in all time treatments; this is unlike thermotherapy in the MSXJ hybrid whose higher meristem survival rate was achieved at the lowest temperature.

Thermotherapy efficiency was verified following the protocol proposed by Torres et al. (2013), mainly in the temperature/time combination of treatments from 40 to $59^{\circ} \mathrm{C}$ for $4 \mathrm{~h}$; they found that this method eradicates PRSV in the MSXJ hybrid. Likewise, these authors were successful in the sanitation of Sweet potato feathery mottle virus (SPFMV), Sweet potato mild mottle virus (SPMMV), Sweet potato latent virus (SPLV), Sweet potato chlorotic fleck virus (SPCFV), Sweet potato mild speckling virus (SPMSV), Sweet potato calico-like virus (SPCaLV), and Citomegalovirus (CMV), as well as reducing the number of sweet potato plants infected with Sweet potato virus $G$ (SPVG) and Sweet potato chlorotic stunt virus (SPCSV) at $21 \%$ and $7 \%$, respectively. Aqleem et al. (2016) managed to reduce Potato leaf roll virus (PLRV) incidence to $16.66 \%$ by treating the propagated potato vitroplants infected with this virus at $37^{\circ} \mathrm{C}$ for $2.0,2.5$, and 3.0 $\mathrm{h}$, which is similar to results indicated by Sulistio et al. (2015), who evaluated two thermotherapy treatments. The first treatment consisted of exposing the tissues at $37^{\circ} \mathrm{C}$ for $4 \mathrm{wk}$ in an incubator and the second with a water bath at $45^{\circ} \mathrm{C}$ for $60 \mathrm{~min}$, eliminating Shallot latent virus (SLV) in all exposed plants in both treatments. These results showed a greater scope than those exhibited in patchouli (Pogostemon cablin) (Noveriza et al., 2012) in which therapy did not eliminate the virus in any of the time treatments $(10,20$, and $30 \mathrm{~min})$ even when higher temperatures $\left(50,55\right.$, and $\left.60{ }^{\circ} \mathrm{C}\right)$ than those of thermotherapy in the MSXJ hybrid were used. When these treatments are compared with those of Rukarwa et al. (2010) using conventional thermotherapy $\left(32{ }^{\circ} \mathrm{C}\right.$ for $8 \mathrm{~h}$ in darkness and/or at $36{ }^{\circ} \mathrm{C}$ for $16 \mathrm{~h}$ light for $4 \mathrm{wk}$ ), it is possible to verify that they did not completely eliminate SPCSV even when thermotherapy was combined with meristem cultivation. Similarly, Bota et al. (2014), in their experiment to obtain virus-free Vitis vinifera L. tissues, determined the low effectiveness of thermotherapy (20\%) using a thermal chamber at $37.5 / 34.0^{\circ} \mathrm{C}$ (day/night) for $40 \mathrm{~d}$. 
In all the mentioned sanitation studies (meristem culture and thermotherapy), RT-PCR was used to confirm the absence/ presence of the viruses because of the high sensitivity that this technique has in low amounts of viral load, as well as in some nanograms of the samples. Hernández-Guzmán et al. (2014), in their study of potato, explain that the main advantage of this method is that it prevents the diagnosis of false negatives or positives (situation that can happen with serological methods) to the specificity of the primers being used that only amplify the region specific to the virus, which are therefore, an effective method in sanitation techniques in which the main objective is to eliminate one or more viruses. Likewise, it is established that the viral titers detected by RT-PCR range between $4 \times 107$ and $6 \times 108$ and are sensitive enough to recognize an asymptomatic plant, which is why it is also ideal to perform the tests prior to the sanitation treatment. Among their results, these authors indicate that the viral load from the inoculum source is closely related to the transmission efficiency of the vector toward other plants, that is, less virus titer leads to less spread of the disease, and this virus accumulation is proportional to the inoculum source, especially since it is a non-persistent transmission. This is the case of the PRSV vectors because the virus does not replicate inside the insect, so that establishing previously healthy plants (virus-free) could be a solution to progressively reduce transmission between crops, especially in genotypes, such as the MSXJ hybrid, with tolerance to pathogens and limiting repercussions on production yield and fruit quality. In-depth research of plant-pathogen interactions is necessary. Together with other preventive measures (biological barriers, leaf pruning, etc.) and good agricultural practices, hese results should be considered because they open a promising prospect to limit the spread and effects of PRSV in our country.

\section{CONCLUSIONS}

According to the reverse transcription polymerase chain reaction (RT-PCR) tests, there was a high presence $(87.7 \%)$ of Papaya ringspot virus (PRSV) in the papaya MSXJ hybrid mother plants established in the field. There was no representative contrast between conditions in the response of regeneration and differentiation in the apical meristems of the MSXJ hybrid. However, there was a higher plant survival rate (87\%) when the apical meristems were under etiolation as compared with those regenerated under photoperiod (21\%).

When the apices were subjected to thermotherapy, the highest survival rate $(99.92 \%)$ was obtained at $40{ }^{\circ} \mathrm{C}$ for $4 \mathrm{~h}$; therefore, there were high tolerance rates of this papaya MSXJ hybrid.

Sanitation performed in the vitroplants of the papaya MSXJ hybrid, confirmed as infected with PRSV, was effective and the apical meristem culture obtained $100 \%$ regenerated and healthy plants. Thermotherapy had the best sanitation rate at $80.2 \%$, so these techniques are efficient in rehabilitating PRSV.

\section{REFERENCES}

Al-Taleb, M.M., Hassawi, D.S., and Abu-Romman, S.M. 2011. Production of virus free potato plants using meristem culture from cultivars grown under Jordanian environment. American-Eurasian Journal of Agricultural \& Environmental Sciences $11: 467-472$.

Aqleem, A., Muhammad, A., and Asad, A. 2016. Use of hot water-thermotherapy to free potato tubers of Potato leaf roll virus (PLRV). International Journal of Life Sciences Scientific Research 2:155-162.

Bayoudh, C., Elair, M., Labidi, R., Majdoub,A., Mahfoudhi, N., and Mars, M. 2017. Efficacy of tissue culture in virus elimination from caprifig and female fig varieties (Ficus carica L.) Plant Pathology Journal 33(3):288-295.

Bota, J., Cretazzo, E., Montero, R., Rosselló, J., and Cifre, J. 2014. Grapevine fleck virus (GFkV) elimination in a selected clone of Vitis vinifera L. cv. Manto negro and its effects on photosynthesis. Journal International des Sciences de la Vigne et du Vin 48:2-10.

Cabrera-Mederos, D., García Hernández, D., Caballero-Álvarez, M.W., García-Mena, y P.L., Portal-Villafaña, O. 2011. Manejo de la mancha anular de la papaya mediante el uso de malla antiáfidos en viveros de Carica papaya L. var. Maradol roja. Fitosanidad 15:241-244.

Cabrera-Mederos, D., García, H.D., González, J.E., y Portal, O. 2013. Manejo de epifitias del Virus de la mancha anular de la papaya utilizando barreras de Zea mays L. en Carica papaya L. Revista de Protección Vegetal 28:127-131.

Chalak, S.U., Hasbnis, S.N., and Supe, V.S. 2017. Papaya ring spot disease management: A review. Journal of Pharmacognosy and Phytochemistry 5:1911-1914.

Cheong, E.J., Mock, R., and Li, R. 2012. Elimination of five viruses from sugarcane using in vitro culture of axillary buds and apical meristems. Plant Cell, Tissue and Organ Culture 109:439-445. 
Deepthi, D.C., and Makeshkumar, T. 2016. Elimination of Cassava mosaic disease through meristem culture and field evaluation for yield loss assessment in Cassava genotypes. Journal of Root Crops 42:45-52.

Dugassa, G., and Feyissa, T. 2011. In vitro production of virus-free sweet potato [Ipomoea batatas (L.) Lam] by meristem culture and thermotherapy. SINET: Ethiopian Journal of Science 34(1):17-28.

Dziedzic, E. 2008. Elimination of Prunus necrotic ring spot (PNRSV) from plum 'Earliblue' shoot through thermotherapy in vitro. Journal of Fruit and Ornamental Plant Research 16:101-109.

González-Garza, R. 2017. Evolution of diagnostic technics for plant viruses. Revista Mexicana de Fitopatología 35(3):591-610.

Grondeau, C., Samson, R., and Sands, D.C. 1994. A review of thermotherapy to free plant materials from pathogens, especially seeds from bacteria. Critical Reviews in Plant Sciences 13:1, 57-75.

Hernández-Guzmán, A.K., y Guzmán-Barney, M.M. 2014. Detección del virus del amarillamiento de las nervaduras de la hoja de la papa en diferentes órganos de Solanum tuberosum grupo Phureja cv. Criolla Colombia utilizando RT-PCR convencional y en tiempo real. Revista Colombiana de Biotecnología 16:74-85.

Hossain, I., and Levy, C. 2014. Investigating KNOX gene expression in Aquilegia petal spur development. Journal of Emerging Investigators Feb $2.6 \mathrm{p}$.

Kumar, N., Singh, H.S., and Kalleshwaraswamy, C. 2010. Aphid (Aphididae: Homoptera) vectors of Papaya ringspot virus (PRSV), bionomics, transmission efficiency and factors contributing to epidemiology. Acta Horticulturae 851:431-443.

Maynard, K.B., and Bassuk, N. 1996. Effects of stock plant etiolation, shading, banding, and shoot development on histology and cutting propagation of Carpinus betulus L. fastigiata. Journal of the American Society for Horticultural Science 121:853-860.

Megchún-García, J.V., Rodríguez-Lagunes, D.A., Castañeda-Chávez, M.R., Murguía-González, J., Lango-Reynoso, F., and Leyva-Ovalle, O.R. 2017. Thiamethoxam in papaya (Carica papaya Linnaeus) agroecosystems. International Journal of Environment, Agriculture and Biotechnology 2:874-880.

Mirafuentes, F., y Santamaría-Basulto, F. 2014. MSXJ, híbrido de papaya sin carpeloidía para el sureste de México. Revista Mexicana de Ciencias Agrícolas 5:1297-1301.

Noveriza, R., Suastika, G., Hidayat, S.H., and Kartosuwondo, U. 2012. Elimination of Potyvirus causing mosaic diseases in patchouli plant using apical meristem culture and hot water treatment on stem cutting. Jurnal Littri 18(3):107-114.

Rodrigues, A.A., de Oliveira-Santos, E., Jun-Takane, R., and Portugal-Pinto de Carvalho, A.C. 2017. Artificial light and growth regulators on the in vitro etiolation of Cattleya labiata. Revista Ciência Agronômica 48:296-302.

Rukarwa, R.J., Mashingaidze, A.B., Kyamanywa, S., and Mukasa, S.B. 2010. Detection and elimination of sweet potato viruses . African Crop Science Journal 18:223-233.

Sánchez-Reyes, G., Jiménez-Casas, M., Jasso-Mata, J., y Rebolledo-Camacho, V. 2016. Etiolación: estrategia para incrementar el enraizamiento de mini-esquejes de Pinus leiophylla Schiede ex Schltdl. et Cham. FORE 22:1-5.

Solís, L.R., Olivera, J., y La Rosa, R.S. 2011. Propagación in vitro de Carica papaya var. PTM-331 a partir de meristemos apicales. Revista Peruana de Biología 18:343-347.

Sulistio, M., Sulistyaningsih, E., and Subandiyah, S. 2015. Elimination of shallot bulb viruses through heat treatment. Indonesian Journal of Biotechnology 20:133-140.

Tamay, D.L., Ibarra, y C., Velasquillo, C. 2013. Fundamentos de la reacción en cadena de la polimerasa (PCR) y de la PCR en tiempo real. Investigación en Discapacidad 2:70-78.

Torres, P.S., Montero, C.W., y Varela, C.I. 2013. Metodología para el diagnóstico viral y la producción de plantas de camote libres de virus. Instituto Tecnológico de Costa Rica (ITCR), Cartago, Costa Rica.

Tuo, D., Shen, W., Yang, Y., Yan, P., Li, X., and Zhou, P. 2014. Development and validation of a multiplex reverse transcription PCR assay for simultaneous detection of three papaya viruses. Viruses 6:3893-3906.

Valderrama, S., Cedano, C., Tenorio, J., Romero, J., y Carbajal, S. 2015. Caracterización sintomatológica y molecular del virus de la mancha anillada del papayo (PRSV) que infecta Carica papaya L. en el norte del Perú. Scientia Agropecuaria 6:241-246.

Vega-Celedón, P., Canchignia Martínez, H., González, M., y Seeger, M. 2016. Biosíntesis de ácido indol-3-acético y promoción del crecimiento de plantas por bacterias. Cultivos Tropicales 37:33-39. doi:10.13140/RG.2.1.5158.3609. 